\title{
The Involvement of Social Media as a Discourse Social Tasikmalaya Residents for the Implementation of the Local Election in the Pandemic Period
}

\author{
Lisda Nurul Romdoni ${ }^{1, *}$, Karim Suryadi ${ }^{2}$ \\ ${ }^{1,2}$ Universitas Pendidikan Indonesia, Bandung, Indonesia \\ *Corresponding author.Email: lisdaromdani@upi.edu
}

\begin{abstract}
Corona Virus Disease 2019 or what we usually call Covid-19 has currently hit the country of Indonesia, with the transmission of the virus that is rapidly spreading. This is because humans get threats that can affect their health. Not only that, this virus can also affect social, economic and political aspects of government. The simultaneous Local Election in 2020 is a form of democracy for the Indonesian nation, the purpose of this writing is to find out how the involvement of social media as a discourse social Tasikmalaya residents for the implementation of the local election in the pandemic period. This research was conducted using literature study method or research with literature study, namely the collection of data and information from scientific journals and books as well as research results. Such is the process of data obtained that the holding of local head elections in a pandemic reaps pros and cons. The media is a public space that is used by citizens in realizing their participation, and the manifestation of a citizen's democratic attitude can be seen from his role through the public space in his decision-making process. Citizens in interpreting democracy today are how to get the freedom to express their opinions to guarantee health and safety in fulfilling their rights. This freedom where the position of the media can be used as a space for citizen democracy in producing a consensus of every individual idea that can be considered by the government in determining policy. Then citizenship skills which consist of citizen skills called intellectual skills to participate in the life of the nation and state. This is closely related to how citizens respond well to all phenomena related to citizenship issues. Thus, the media as a means of political discussion among the community can be said to be the meaning of democracy that can be seen by every individual in the practice of citizenship.
\end{abstract}

Keywords: Democracy, Media, Local Election.

\section{INTRODUCTION}

The current position of social media in Indonesia is an interesting phenomenon, where the development of media in society has entered the era of disruption. The rapid development of social media in reality does not go hand in hand with the development of education in its field, according to Bungin (2008), this happens based on two needs, namely messages on social media can quickly introduce products to the public, and the characteristics of the community that cause them to believe that messaging on social media is their way of seeing their current needs. The use of social media varies greatly based on the distribution of population in Indonesia. The position of the media as a public space is currently needed as a communication and also as a rational discussion space. As another public space, social media is also used as a platform to express individual views so that it becomes a material for discussion related to the implementation of Pilkada during this pandemic. With this social media, users or the public have the opportunity to express their opinions and arguments as a form of participation.
The concept of social media as a discourse space is a necessity based on democratic values. Because the success of democracy cannot be separated from the role of the community and also the government, in this case the organizers of regional head elections. The growing public awareness of the importance of democracy, the democratization process in Indonesia becomes very important by paying attention to existing values. In the current era of technology, it can be an opportunity to give people freedom in providing input on government policies through social media. Of course, this is also an opportunity for potential candidates who can campaign through social media.

Therefore, the existence of the media has a very strategic position to facilitate citizen participation in conveying their ideas as a form of democratic development in Indonesia. Referring to PKPU Number 13 of 2020, regarding the implementation of the campaign, it can also be carried out in various media including social media which is currently a public space for the community. That way, through social networks, people can actively participate in reviving democracy in Indonesia. 
However, the functioning of the media as a public space suggestion is common if there are pros and cons, then this shows the social reality that can be found in the dimensions of general awareness to individual awareness in an interacting group (Parera, 2013). Therefore, social media as a means of community social discourse in determining their thoughts in interpreting the existing phenomenon, namely the implementation of the Regional Head Election.

The involvement of social media is part of the responsibility for all citizens. This study also develops the substance of civic education as the goal of producing citizens who are not only capable in curricular and extracurricular aspects, but also capable in aspects of the socio-cultural dimensions. Thus, the involvement of social media as a means of discourse is expected to be able to see social media users who have provided an accessible discussion space for the public so that they are able to realize a participatory attitude that upholds democratic values.

\section{THEORETICAL REVIEW}

\subsection{Democracy Theory}

Substantively democracy is a basic principle of how a country stands and runs its government. In the context of national life, democracy is defined as the sovereignty of the people, so a government rotation system must be carried out. This also happened in the democratic state of Athens, where citizens took turns holding power so as not to be occupied by a continuous government. Democracy as we have learned is defined as government of, by, and for the people. Therefore, the highest power is in the hands of the people and the representatives of the people who are elected through general elections. This is where the Indonesian state adopted democracy in order to avoid authoritarian rule.

Furthermore, the meaning of democracy is seen from the empirical side, according to Afan Gafar (2006) can be seen based on several indicators as follows: (1) Accountability which is defined as the responsibility of the power holder, (2) Rotation of power, (3) open political recruitment, (4) implementation of democratic elections, and (5) citizens whose basic rights are fulfilled by the government (HAM). Thus, the relationship between democracy and human rights can be seen through the practices of state administration by the authorities. Thus, Sari (2003) explains how the indicators of human rights enforcement in a democratic country, namely: (1) There is a guarantee of freedom of expression, (2) freedom to make choices in elections, (3) freedom of the press, (4) freedom of religion, (5) freedom to live, (6) political participation.

Democracy is interpreted as a form of government that makes the people the subject, and also means a system of government that is based on the sovereignty of the people. Therefore, democracy can be interpreted as a form of government in which citizens exercise the same rights not personally, but through people's representatives who sit in the people's representative institutions.

\subsection{Mass Media Space}

Indonesia is a country with quite a large number of internet users. The growth of internet users continues to increase every year. Based on data from We are Social and Hootsuite (2019), the population of internet users in Indonesia grew by $13 \%$ (January 2018 - 2019), and this is above the average growth of digital internet users in general of around $9.1 \%$.

The presence of the internet has brought Indonesian people into the global world. Digital growth in Indonesia is highly expected for a better Indonesian democracy, but the digital divide from year to year is shown by the many cases and problems that occur in the digital world. According to We are Social \& Hootsuite (2019), there are several factors in this gap. First, where there is still a lack of internet penetration in Indonesia. Second, the social gap between information-rich and information-poor, and thirdly the democratic gap, where the use of digital to participate in political life is still considered lacking.

Seeing the high number of internet users, this is very potential in developing well-informed citizens' activities in developing a knowledge base on politics in social media as an improvement in democracy in Indonesia. This is contained in a book written by Colenan (2017), namely how information technology can be interwoven dialectically through the actions of its citizens. With this dialectic, communication between the government and its citizens can be established and capable of selfrepresentation.

The internet as an electronic mass media space has a strong role in increasing free and active discussions for its users. This is what some researchers reveal about the role of social media as a democratic space that has an important part in interacting that is bottom-up. So this shows that there is an active involvement that is expected by the audience to get information and find the desired information. Similarly, what was written by Mark Slouka (in Bungin 2008) where he said that the space formed by cyberspace is an electronic space that imitates forms of social life.

Enforcing democracy in public spaces during the pandemic is a new challenge for the Indonesian nation. Andriansyah (2020) stated that the safety of implementing democracy during a pandemic is the health, security, and welfare of citizens. Therefore, government action in ensuring the safety of citizens is the goal in the implementation of this regional head election. The research conducted by Hergianasari (2020) is a representation where the results of the study show that citizens following the health protocol do not reduce the essence of the implementation of a democratic party.

Seeing the implementation of regional head elections during a pandemic is a consensus that causes a lot of conflict in it. It is hoped that there will be a democratic political system that regulates and resolves conflicts in 
the form of a good agreement. The theory adopted as a supporter of the above statement, namely from Habernas where the phenomenon of democracy that occurs is deliberative democracy where there is a dialogue that can dilute the conflict that occurs, so that the conflict is muted through deliberation.

There are 2 important things how to assemble digital politics for Indonesian citizens. First, better internet domain control becomes a control for the state to monitor, and the public to access it. Second, the intensity of internet use, especially social media, can be interpreted as a leisure activity or pleasure. In this regard, it is necessary to formulate the right parameters to occupy the position of social media in society, namely whether the internet as social media becomes a discourse space for the involvement of a citizen.

However, it should be understood that this is also a challenge for Indonesia where changing the habits or cyber culture of the Indonesian people who still have a low level of political participation, this of course requires a special strategy so that people involve themselves in the digital space as the development of a communication culture in the public sphere.

The media as a democratic space and a vehicle for ideas among citizens can produce a consensus and group agreement as a result of the transformation of individual ideas that are put together. Therefore, the media as a means of political discussion among the public, can be said as a democratic process where it can be seen that every individual gets the same position in the practice of citizenship.

\section{METHODS}

This study uses a qualitative research design with phenomenological methods. A qualitative approach is used so that researchers are more flexible in analyzing various phenomena related to the construction of Tasikmalaya residents towards the implementation of the Pilkada during a pandemic in a comprehensive civics education perspective. This shows that a qualitative approach is used to examine the condition of natural objects so that research results emphasize more on meaning, where researchers can build a complex picture by analyzing words or views of information in detail (Creswell, 2008).

The qualitative approach is also process-oriented where the implementation will find a number of data and facts to be studied more deeply. Therefore, Alwasilah (2012) states that this approach focuses on understanding meaning from the participant's perspective, understanding it in a certain context, thus giving rise to a data-based theory that seeks to better understand the process rather than the product, as well as explain the causal relationships of events that occur.

\section{RESULT AND DISCUSSION}

The development of the media is one of the democratic spaces that has a high ability to create new social realities. All information and news proclaimed by the media is seen as objective information because it is considered to be used as a reference in thinking. In fact, the information or news that is spread should be reconfirmed so as to avoid fake news or fake news. Suryadi (2008, p. 146) explains the relationship between political news and social life because the intensity of national political reporting increases then the role of mass media in political development has also been determined by the political system, then the level of participation is determined by one's cognitive response.

The study of democracy and the public sphere is defined as technology and information increasingly take on a role in modern life. This also brings democracy based on: 1) shared sovereignty which results in a condition of free discussion among citizens, 2) the presence of occasional differences of opinion creates political injustice among those whose ideas are limited, 3) freedom of information indicates the quality of democracy in discussing and taking decisions. decisions, 4) with the emergence of new ideas in the media can invite political discussions.

In this case, the media facilitates public communication by distributing information, and social movements that invite discussion between users. Thus the media that becomes a virtual public space has openness, mass communication, and socio-democratic changes. Communication that occurs not only between communities, but communication can connect the government and its people. So that social media can actually facilitate citizen participation in politics so that they become supervisors in a government.

Thus, this technological development provides an opportunity for its citizens not to become objects but become media subjects, because Berger \& Luckmann (2013) view humans as individuals who are free to develop their knowledge and thoughts. So that every citizen has the same right to have an opinion, to give ideas, to criticize the government. Thus, humans have the freedom to act actively in response to what is received in their daily lives.

When viewed from the research findings that have been described, there are at least two communication patterns that are built by the social media user community. Namely, the pattern of public communication and the pattern of communication with the community. That is, these two patterns have shown the existence of a self-image built by media users in front of the audience. For example, in the pattern of public communication, a person can use formal language as if he has high knowledge, accompanied by a serious attitude and occasionally becomes an observer in political activities. Meanwhile, community communication is contrary to the pattern of public communication. 
The following explanation from Mulyana (2005) sees the pattern of public communication consisting of structuring that connects institutions with officials in dialectical interactions, meaning that the communication that occurs is formal and has good language so that it appears to have high intellectuality. Meanwhile, community communication is an interaction that aims to share information in the community whose members can remember the personal characteristics of other members.

After the message is communicated, a discourse occurs between residents who use social media on the topics reported by the constructor so that there is a process of exchanging ideas and ideas, transforming information and so on. The discussions built by media users function as social control for the government in determining policies. Through this discussion process, citizens can develop the critical capacity of citizens in reviewing problems.

Discussions in this media have developed as a form of digital democracy, Habernas where the phenomenon of democracy that occurs is deliberative democracy where there is a dialogue that can dissolve conflicts that occur, so that conflicts are muffled through deliberation. Liberative democracy for the state today no longer determines policies in a closed space, but the public through the media and their organizations exert influence in the policy process. Looking at the idea of democracy theory according to Habernas, it can be interpreted that regardless of whether or not Habernas' views on deliberative democracy are compatible with the current conditions in Indonesia, where Indonesia highly respects religious values, it is necessary to understand that adhering to the notion of democracy in government must be based on the will of the people. and expectations of the people.

In discussions among citizens, creating a reality that departs from opinions that are widely understood by others, so that public space is created as a means of exchanging ideas of citizens about the social life they experience. By submitting opinions in the discussion, it can invite the formation of public opinion in increasing citizen participation. In this case, social media becomes a means of community discourse and can collaborate by following the trends that occur. Thus, public space is created and understood as a mass media that has a distinctive discourse in gathering individuals in a container so that they become political forces.

The function of the media is not only as a place to channel aspirations, but also as a means of social control that contributes to checks and balances between the government and its people. And this condition is indeed a form of democracy with dialogue that can dilute the problems that occur. The problems that occur can actually be muted and this is the expected social control function, through deliberation and the creation of public spaces and places for citizen participation.

The involvement of social media as a means of discourse has a strong role in increasing active discussions for the internet user community. Many of these discussions occur on the Facebook and Instagram platforms, which often show collective actions of understanding which eventually turn into an action of support and even opposition to a policy. Thus, social media currently has a position as a very productive policy control tool. The public space created can be an arena where many people come to have discussions. Therefore, this is a place to express opinions, display expressions, bring up collective action, build mature thinking patterns, digital democracy space, and can also be used as a place where you can find freedom to express yourself without the boundaries of space and time.

The position of civic education in the involvement of social media as a means of citizen discourse is democratic education which can be understood together that there are freedom rights that everyone has. The media as a democratic space and a vehicle for ideas among citizens can produce a consensus and group agreement as a result of the transformation of individual ideas that are put together. Therefore, the media as a means of political discussion among the public, can be said as a democratic process where it can be seen that every individual gets the same position in the practice of citizenship.

\section{CONCLUSION}

Thus, based on the various explanations above, it can be concluded that social media as a discourse space can produce two sides, first increasing public political participation and also becoming political education as a form of democracy. With the existence of social media platforms that can provide opportunities for the public to understand politics and government. With social media as a public space, we can build communication and discuss other issues so that we can change the pattern of communication to be more dialogical and critical. Thus, with the opening of social media as a public space for the wider community, it can increase citizen participation that is wider and more open.

\section{REFERENCES}

[1] Alwasilah, A.C. Pokoknya Penelitian Kualitatif. Jakarta: Pustaka Jaya. 2012

[2] Bungin, M.B. Konstruksi Sosial Media Massa: Kekuatan pengaruh media massa iklan televisi dan keputusan konsumen serta kritik terhadap Peter L. Berger dan Thomas Luckmann. Jakarta: Kencana, 2008.

[3] Bungin, M.B. Sosiologi Komunikasi: Teori, Paradigma, dan Diskursus Teknologi Komunikasi di Masyarakat. Jakarta: Kencana Prenamedia. 2014

[4] Coleman, S. Can the Internet Strengthen Democracy?. Polity. 1st Edition. 2017.

[5] Creswell, J. W. Educational Research (Planning, Conducting and Evaluating Quantitative and 
Qualitatif Research. California: University od Nebrasca-Licoln. 2008.

[6] Gaffar, A. Politik Indonesia, Transisi menuju Demokrasi. Yoyakarta: Pustaka Belajar. 2016

[7] Hergianasari, P. Electoral Distancing: Alternatif Penyelenggaraan Pemilihan Kepala Daerah 2020 Ditengah Covid-19 Di Indonesia. Magistrorum tt Scholarium: Jurnal Pengabdian Masyarakat, vol. 1(1), 112-121. 2020.

[8] Mulyana, D. Ilmu Komunikasi: Suatu Pengantar. Bandung: PT Rosda Karya. 2005.

[9] Parera. Pengantar dalam Buku Peter L Berger dan Luckmann. Tafsir Sosial atas Realitas. Diterjemahkan oleh Hasan Basari. Jakarta: LP3ES. 2013.

[10] Riyanto, A.D. Hootsuite (We are Social): Indonesian Digital Report 2019. https://andi.link/hootsuite-we-are-socialindonesia-digital-report-2019/. 2019. diakses pada tanggal 10 November 2020. Pukul 06.45 WIB.

[11] Sari, E. Demokrasi dan Hak Asasi Manusia. Jurnal Demokrasi, vol. 2(1). 2003.

[12] Suryadi, Karim. Political News and Early Voter Alienation: Why does not Political Knowledge Lead Early Voters to Use their Right to Vote?. Indonesian Journal of Communication Studies, 1(2). 2008 